\title{
Mountain soils under a changing climate and land-use
}

\author{
Frank Hagedorn · Jan Mulder • Robert Jandl
}

Received: 1 October 2009/Accepted: 6 October 2009/Published online: 11 November 2009

(C) Springer Science+Business Media B.V. 2009

\begin{abstract}
Mountain ecosystems are currently experiencing the strongest climatic warming and the largest changes in land-use during the last millennia. The impacts of these changes on soils and their roles in the cycling of carbon and nutrients are, however, largely unknown. Here, we define mountain soils as soils from mountainous areas with cool summers and cold winters and thus, soils from ecosystems that are influenced by snow and ice and where biogeochemical processes are limited by temperature. Because climatic conditions, soil properties, plant species and productivity vary at a small scale in mountains, they provide a unique natural but a seldom used laboratory to study soil processes. In this special issue, we compile different studies on soils from European mountains, reaching from the functioning of mountain soils along natural climatic gradients to responses of greenhouse gas fluxes from mountain
\end{abstract}

F. Hagedorn $(\square)$

Swiss Federal Institute for Forest, Snow and Landscape Research (WSL), 8093 Birmensdorf, Switzerland e-mail: hagedorn@wsl.ch

J. Mulder

Department of Plant and Environmental Sciences, Norwegian University of Life Sciences, 1432 Aas, Norway

R. Jandl

Austrian Forest Research Center (BFW), 1131 Vienna, Austria soils to experimental warming, soil frost and changes in precipitation.

Keywords Alps $\cdot$ Carbon cycling $\cdot$ Climatic change - Decomposition - Forest management . Land-use change $\cdot$ Snow cover $\cdot$ Soil organic matter . Soil frost $\cdot$ Winter

\section{Introduction}

Mountain ecosystems have much in common with more intensively studied high-latitude ecosystems with respect to slow soil formation, short growing season and considerable changes in vegetation cover due to climatic changes during the last decades. However, there a number of important differences between these two 'cold' ecosystems: (i) Mountain ecosystems particularly those of Central Europe have much more intensively been used by humans for centuries. (ii) High altitudes of the temperate zone generally receive more precipitation, winter temperatures are warmer, and the snow cover is thicker. Consequently, soils are insulated better and soil frost is less deep. (iii) Mountain soils on slopes are usually well drained, and thus wet- and peatlands are less common than at high latitudes. (iv) Natural disturbances such as soil erosion, rock fall, and avalanches play a more important role in ecosystem functioning. 
Already 80 years ago, Jenny (1929) noted that soils of alpine areas are darker and richer in humus than those of lowlands. Until now, only a few systematic studies support this early suggestion of a larger $\mathrm{C}$ accumulation in high altitude soils. While soil inventories in Switzerland and Austria do not reveal a significant altitudinal increase in total $\mathrm{C}$ storage from lowland forests to the treeline (Perruchoud et al. 2000; Weiss et al. 2000); Leifeld et al. (2009) and Sjögersten et al. (2003) observed increasing fractions of particulate and labile SOM with increasing altitude in grassland and natural treeline ecosystems. So far, we can only speculate about the reasons for a similar total $\mathrm{C}$ storage despite a different distribution among SOM pools at high and low altitudes. Apparently, there is a 'balancing out': smaller $\mathrm{C}$ inputs from plant detritus and a lower stabilization of SOM by less weathered mineral surfaces are outweighed by a preservation of SOM due to harsher climatic conditions at high altitudes (De Deyn et al. 2008; Kammer et al. 2009). The storage of large amounts of organic $\mathrm{C}$ in labile pools in mountain soils implies a high vulnerability of these soils to loose $\mathrm{C}$ when abiotic and biotic conditions are altered by a changing climate and land-use.

\section{Carbon cycling in a warmer climate}

Climatic warming in Central and Northern European mountain regions is stronger than anywhere else (IPCC 2007; Rebetez and Reinhard 2008). In the Swiss Alps, mean annual temperatures have increased by $0.57^{\circ} \mathrm{C}$ per decade, but by 'only' $0.25^{\circ} \mathrm{C}$ decade $^{-1}$ in the Northern Hemisphere. The impact of soil warming on the $\mathrm{C}$ balance of terrestrial ecosystems is uncertain because rising temperature enhances both $\mathrm{C}$ gains through net primary production, but also respiratory $\mathrm{C}$ losses. At the alpine treeline, Hagedorn et al. (2010, this issue) showed that one season of $4^{\circ} \mathrm{C}$ soil warming, indicative for hot summers, turned ecosystems into a $\mathrm{C}$ source because it increased SOM decomposition much more than $\mathrm{C}$ uptake through plant growth. The tracing of simultaneously added ${ }^{13} \mathrm{C}$ depleted $\mathrm{CO}_{2}$ revealed a greater warming response of the mineralization of older SOM than of root respiration. However, it remains uncertain, how persistent in time these effects are, how fast the substrate availability is declining in these alpine soils with thick organic layers, if microbial communities and plant are acclimatizing, or if an accelerated SOM mineralization will increase nutrient availability and consequently, plant growth (Luo et al. 2001; Melillo et al. 2002).

\section{Snow, frost and $\mathrm{N}_{2} \mathrm{O}$}

Snow cover plays a key role for biogeochemical cycles in mountain soils (e.g. Williams et al. 2009). The ongoing and predicted decreases in snow fall counter-intuitively could lead to colder soils by reducing the snow cover and thus, to longer frost periods and changes in microbially driven processes. Bursts of $\mathrm{N}_{2} \mathrm{O}$ are a spectacular but still not well understood phenomenon of freeze and thaw cycles. In a snow removal experiment, Goldberg et al. (2010, this issue) showed that the increased soil freezing and thawing resulted in almost tenfold enhanced $\mathrm{N}_{2} \mathrm{O}$ fluxes. So far, these $\mathrm{N}_{2} \mathrm{O}$ bursts at frost have mostly been attributed to substrate accumulation in small water films, while flushes of $\mathrm{N}_{2} \mathrm{O}$ at thawing have been ascribed to enhanced microbial $\mathrm{N}_{2} \mathrm{O}$ production in the topsoil due to increased substrate availability. Vertical gradients of concentrations together with isotope signatures in the study of Goldberg et al. (2010, this issue) indicated that microbial $\mathrm{N}_{2} \mathrm{O}$ production and reduction of $\mathrm{N}_{2} \mathrm{O}$ to $\mathrm{N}_{2}$ occurred only marginally in frozen soil layers. Consequently, elevated $\mathrm{N}_{2} \mathrm{O}$ fluxes in the late winter originated mainly from the release of accumulated $\mathrm{N}_{2} \mathrm{O}$ from the subsoil, which was not consumed when the topsoil was frozen.

\section{Decreasing soil aggregation with increasing frost}

Frost and thaw cycles do not only affect $\mathrm{C}$ and $\mathrm{N}$ dynamics, but first and foremost soil structure, which is a key factor for soil stability, but also of SOM dynamics as well as water and nutrient cycling. Making use of a natural climatic gradient through a permafrost zone in the French Alps, Cécillon et al. (2010, this issue) found that soils with a mean annual temperature of $5^{\circ} \mathrm{C}$ and frequent frost-thaw events were much less aggregated than $5^{\circ} \mathrm{C}$ warmer soils. The sizes and forms of soil aggregates indicated an increased biological and physical formation of aggregates in warmer soilsthe consequences are a decreased erodibility of warmer 
soils. The smaller aggregation may also be one of the explanations why high altitude soils store less $\mathrm{C}$ in stabilized form.

\section{Climate change effects on inorganic nitrogen and DOC in runoff from mountain soils}

Snow pack thickness is an important driver of soil carbon and nitrogen dynamics and thus of surface water quality. In a recent snow manipulation experiment in the Norwegian mountains, addition of snow induced a soil warming and resulted in increased fluxes of inorganic $\mathrm{N}$ during spring runoff, whereas snow removal causing soil frost had no systematic effect (Kaste et al. 2008). In contrast, neither the soil warming nor soil frost in winter had a pronounced effect on concentrations and fluxes of dissolved organic carbon (DOC). In summer, DOC in runoff from mountain soils is strongly affected by precipitation volume. Concentrations tend to increase at greater flow rate, due to increasing contribution of DOC-rich surface runoff to total discharge. Here, Haaland and Mulder (2010, this issue) suggest that DOC in runoff from shallow organic mountain soils is controlled by a pool of potential DOC, which is relatively large, not rapidly depleted and easily replenished, thus representing a major buffer for DOC concentrations in runoff from mountainous catchments.

\section{Soil microbial communities in mountain soils}

Microbial communities adapt to their environmental conditions. While microbial succession on retreating glacier have extensively been investigated (e.g. Bardgett et al. 2007), there are hardly any systemic studies at different altitudes in montane and alpine ecosystems. Along a small scale climate gradient across a mountain valley, Blagodatskaya et al. (2009, this issue) showed that colder and wetter sites in north-east facing slopes have higher fungal-bacterial ratios than south-west facing slopes. This is in agreement with relative increases of fungi with rising altitude in topsoils of alpine grassland (Margesin et al. 2009), which might reflect increasing SOM contents in topsoils and a decreasing fertility.

The low nutrient status of high altitude soils very likely affects not only microbial communities but also nutrient cycling through the low litter quality of high altitude plants. Northup et al. (1995) suggested that the production of polyphenols by plants increase with decreasing soil fertility as an adaptive attribute to enhance plant's competitiveness for limiting $\mathrm{N}$. For nutrient-poor acidic Czech mountain soils, Bárta et al. (2010, this issue) demonstrated that $\mathrm{N}$ mineralization was smallest from litter with the highest contents of phenolics that also had the lowest phosphorus (P) availability. The $\mathrm{P}$ availability and amount of phenolics strongly influenced the initial composition of microbial communities. While the amount of phenolics influenced the colonization of fungal community, the availability in $\mathrm{P}$ was connected more with bacterial colonization. Most interestingly, the composition of the microbial community changed during the initial phase of decomposition and these changes again depended on the contents of available $\mathrm{P}$ and phenolics.

\section{Impact of land-use changes}

Due to socio-economic pressures, the changes in landuse in European mountain regions are dramatic. While on marginal land, land is abandoned, land use on productive site in the lowland but also in valley bottoms of mountainous areas is intensified. For instance, in the Swiss Alps, the forested area above $1,400 \mathrm{~m}$ a.s.l. is increasing by $7 \%$ per decade, twice as much as at lower altitudes (Bolliger et al. 2008). In the Eastern Central Alps, between 35 and $70 \%$ of the steep and high-altitude area but only $7 \%$ of the favourable valleys has been abandoned during the last 150 years and reforested (Tasser et al. 2007). The effects of these dramatic changes on soils have hardly been studied. Morejamane et al. (2010, this issue) investigated the impact of forest management practises on methane emissions in Northern England. Their results showed that drainage of afforested peaty soils decreased methane emissions while mounding and fertilisation with NPK increased the $\mathrm{CH}_{4}$ effluxes.

\section{Synopsis and outlook}

Mountain ecosystems are currently experiencing the strongest climatic warming and the largest changes in land-use during the last millennia. The research 
presented in the contributions to this special issue gives new insights into the responses of mountain soils to these changes. There are, however, several important open questions: (1) Why do contents of labile soil organic matter increase with altitude? Does this imply that high altitude soils will loose $\mathrm{C}$ in a warming climate because mineralization responds more rapidly to climatic changes than SOM stabilization? (2) How are the structures and functions of soil microbial communities and soil fauna linked to climatic conditions and specific properties of mountain ecosystems? (3) What are the effects of intraannual and long-term climatic warming and snow cover changes on ecosystems $\mathrm{C}$ balance and the role of soils as a source or sink for greenhouse gases? How does an upward shift of vegetation zones affect soil properties? (4) How do natural disturbances such as landslides and avalanches affect $\mathrm{C}$ and nutrients cycling and which influence does this have for vegetation growth and distribution? (5) How does land abandonment affect soil functions? Does an expansion of forest into grasslands increase soil $\mathrm{C}$ storage? Mountains provide a fantastic natural experimental set-up to answer some of these questions, because climatic conditions, soil properties, plant species and plant productivity change drastically within a short distance.

Acknowledgement The papers of this special issue were presented at WSL Birmensdorf, Switzerland, within a Working Group Meeting of COST Action 639 Greenhouse gas Budget of Soils under Changing Climate and Land Use (Burnout).

\section{References}

Bardgett RD, Richter A, Bol R et al (2007) Heterotrophic microbial communities use ancient carbon following glacial retreat. Biol Lett 3:487-490

Bárta J, Applová M, Vaněk et al (2010) Effect of available P and phenolics on mineral $\mathrm{N}$ release in acidified spruce forest: connection with lignin-degrading enzymes and bacterial and fungal communities. Biogeochemistry (this issue). doi:10.1007/s10533-009-9363-3

Blagodatskaya E, Dannemann M, Gasche R et al (2010) Microclimate and forest management alter fungal-tobacterial ratio and $\mathrm{N}_{2} \mathrm{O}$-emission during rewetting in the forest floor and mineral soil. Biogeochemistry (this issue). doi:10.1007/s10533-009-9310-3

Bolliger J, Hagedorn F, Leifeld J et al (2008) Effects of landuse change on carbon stocks in Switzerland. Ecosystems 11:895-907
Cécillon L, de Mello NA, de Danieli S et al (2010) Soil macroaggregate dynamics in a mountain spatial climate gradient. Biogeochemistry (this issue). doi:10.1007/s10533-0099341-9

De Deyn GB, Cornelissen JHC, Bardgett RD (2008) Plant functional traits and soil carbon sequestration in contrasting biomes. Ecol Lett 11:516-531

Goldberg SD, Borken W, Gebauer G (2010) $\mathrm{N}_{2} \mathrm{O}$ emission in a Norway spruce forest due to soil frost: concentration and isotope profiles shed a new light on an old story. Biogeochemistry (this issue). doi:10.1007/s10533-009-9294-Z

Haaland S, Mulder J (2010) Dissolved organic carbon concentrations in runoff from shallow heathland catchments: effects of frequent excessive leaching in summer and autumn. Biogeochemistry (this issue). doi:10.1007/s10533009-9373-1

Hagedorn F, Martin M, Rixen C et al (2010) Short-term responses of ecosystem carbon fluxes to experimental warming at the Swiss alpine treeline. Biogeochemistry (this issue). doi:10.1007/s10533-009-9297-9

IPCC (2007) Climate change 2007: the physical science basis. In: Solomon S, Qin D, Manning M et al (eds) Contribution of working group $\mathrm{i}$ to the fourth assessment report of the intergovernmental panel on climate change. Cambridge University Press, Cambridge

Jenny H (1929) Vegetations-Entwicklung und Bodenbildung. Zweiter Teil: Die alpinen Böden. Denkschrift der Schweizerischen Naturforschenden Gesellschaft LXIII, 297-340

Kammer A, Hagedorn F, Shevchenko I et al (2009) Treeline shifts in the Ural mountains affect soil organic matter dynamics. Glob Change Biol 15:1570-1583

Kaste Ø, Austnes K, Semb Vestgarden L et al (2008) Manipulation of snow in small headwater catchments at Storgama, Norway: Effects on leaching of inorganic nitrogen. Ambio 37:29-37

Leifeld J, Zimmermann M, Fuhrer J et al (2009) Storage and turnover of carbon in grassland soils along an elevation gradient in the Swiss Alps. Glob Change Biol 15:668-679

Luo Y, Shigiang W, Hui D et al (2001) Acclimatization of soil respiration to warming in a tall grass prairie. Nature 413: 622-625

Margesin R, Jud M, Tscherko D et al (2009) Microbial communities and activities in alpine and subalpine soils. FEMS Microbiol Ecol 67:208-218

Melillo JM, Steudler PA, Aber JD et al (2002) Soil warming and carbon-cycle feedbacks to the climate system. Science 298:2173-2176

Mojeremane W, Rees RM, Mencuccini M (2010) Effects of site preparation for afforestation on methane fluxes at Harwood Forest, NE England. Biogeochemistry (this issue). doi: 10.1007/s10533-009-9322-Z

Northup RR, Yu Z, Dahlgren RA et al (1995) Polyphenol control of nitrogen release from pine litter. Nature 377: 227-229

Perruchoud D, Walthert L, Zimmermann S et al (2000) Contemporary carbon stocks of mineral forest soils in the Swiss Alps. Biogeochemistry 50:111-136

Rebetez M, Reinhard M (2008) Monthly air temperature trends in Switzerland 1901-2000 and 1975-2004. Theor Appl Climatol 91:27-34 
Sjögersten S, Turner BL, Mathieu N et al (2003) Soil organic matter biochemistry and potential susceptibility to climate change across the forest-tundra ecotone in the Fennoscandian mountains. Glob Change Biol 9:759-772

Tasser E, Walder J, Tappeiner U et al (2007) Land-use changes and natural reforestoration in the Eastern Central Alps. Agric Ecosyst Environ 118:115-129

Weiss P, Schieler K, Schadauer K et al (2000) Die Kohlenstoffbilanz des österreichischen Waldes und Betrachtungen zum Kyoto-Protokoll. FBVA Umweltbundesamt, Monographien 106

Williams MW, Helmig D, Blanken P (2009) White on green: under-snow microbial processes and trace gas fluxes through snow, Niwot Ridge, Colorado Front Range. Biogeochemistry $95: 1-12$ 